Огляди літератури, оригінальні дослідження, погляд на проблему, випадок з практики, короткі повідомлення УДК 616.314.17-008.1:577.114.4-06:616.33-002.2

DOI 10.11603/1811-2471.2019.v.i4.10790

\title{
ПАТОМОРФОЛОГІЧНІ ОСОБЛИВОСТІ РОЗВИТКУ ЛІПОПОЛІСАХАРИДНОГО ПАРОДОНТИТУ НА ФОНІ ХРОНІЧНОГО АТРОФІЧНОГО ГАСТРИТУ
}

\author{
๑О. С. Беденюк, М. М. Корда \\ Тернопільський національний медичний університет імені І. Я. Горбачевського МОЗ України
}

РЕЗЮМЕ. Запальні захворювання тканин пародонта $є$ однією з найважливіших проблем стоматології. Існує стійкий зв'язок між патологією пародонта і запальними захворюваннями шлунка.

Мета - дослідити патоморфологічні зміни у тканинах пародонта щурів з генералізованим ліпополісахаридним пародонтитом, асоційованим із хронічним атрофічним гастритом.

Матеріал і методи. У щурів моделювали генералізований ліпополісахаридний пародонтит шляхом введення в тканини ясен ліпополісахариду в дозі 40 мкл (1 мг/мл) протягом 2 тижнів. Атрофічний гастрит викликали шляхом інтрагастрального введення протягом 6 тижнів 2 \% саліцилату натрію і 20 мМ деоксихолату натрію. Гістологічні препарати фрагментів верхньої щелепи фарбували гематоксиліном і еозином.

Результати. При генералізованому ліпополісахаридному пародонтиті відбувається реорганізація всіх структурних компонентів тканин ясен. Вона проявляється змінами епітелію слизової оболонки ясен, збільшенням зроговілого і зменшенням остистого шарів, розширенням міжклітинних просторів, зростанням лімфоцитарної інфільтрації, набряком сполучної тканини слизової оболонки, розширенням, кровонаповненням вен і гемокапілярів, потовщенням стінки артерій, набряком аморфної речовини сполучної тканини і пошкодженням їі волокнистих структур. При пародонтиті на фоні гастриту всі структурні зміни проявляються у більшому ступені, ніж при пародонтиті без соматичної патології.

Висновки. Супутній хронічний атрофічний гастрит суттєво погіршує патоморфологічну картину пародонтиту, індукованого у тварин ендотоксином грамнегативної мікрофлори ліпополісахаридом.

КлючовІ СЛОВА: пародонтит; атрофічний гастрит; морфологічні зміни.

Вступ. Запальні захворювання тканин пародонта на сьогодні $\epsilon$ чи не найважливішою проблемою стоматології, що має не тільки медичне, а й величезне соціальне значення, яке зумовлено значною поширеністю пародонтитів, ураженням осіб молодого віку, можливістю впливу пародонтиту на виникнення соматичної патології, відсутністю ефективних методів діагностики, профілактики та лікування цієї патології $[1,2]$. Поширеність пародонтиту в різних країнах світу становить 50$90 \%$ В Україні, залежно від регіону та віку обстежених, поширеність захворювань пародонта досягає 85-95\% [3, 4].

Оскільки пародонт $\epsilon$ невід'ємною складовою цілого організму, важливим фактором, що визначає тяжкість перебігу і прогноз генералізованого пародонтиту, $\epsilon$ наявність супутньої соматичної патології. Епідеміологічні дослідження чітко підтверджують, що цукровий діабет, гіпертонічна хвороба, септичний ендокардит, сечокам'яна хвороба, гепатити й ряд інших захворювань з абсолютною закономірністю поєднуються із ураженням пародонта [5-8]. Стійкий зв'язок наявний між патологією пародонта і запальними захворюваннями шлунка та кишечника [9]. У пацієнтів із хворобами органів травлення патологічні зміни тканин пародонта трапляються в понад 90 \% випадків. Особливості молекулярних механізмів, які лежать в основі впливу хвороб шлунка на патоге- нез пародонтиту, на сьогодні висвітлені недостатньо та потребують детальнішого вивчення. Не дослідженими залишаються патоморфологічні механізми розвитку індукованого ендотоксином грамнегативної мікрофлори ліпополісахаридом пародонтиту, асоційованого з хронічним атрофічним гастритом.

Мета - дослідити патоморфологічні зміни в тканинах пародонта щурів з генералізованим ліпополісахаридним пародонтитом, асоційованим із хронічним атрофічним гастритом.

Матеріал і методи дослідження. Досліди виконані на білих безпородних щурах-самцях масою 160-180 г. У процесі роботи використано 30 тварин, яких утримували на стандартному раціоні віварію відповідно до санітарно-гігієнічних норм. Усі етапи експериментів виконані згідно з Міжнародними вимогами гуманного поводження з тваринами відповідно до «Європейської конвенції із захисту хребетних тварин, що використовуються в експериментальних та інших наукових цілях» (Страсбург, 1986).

Піддослідні тварини були поділені на групи: I - інтактні щури (контроль); II - тварини з моделлю генералізованого ліпополісахаридного пародонтиту. Щурам цієї групи в тканини ясен вводили ліпополісахарид (ЛПС) E. Coli («Sigma-Aldrich», США). ЛПС розводили на стерильному фізіологічному розчині і вводили за допомогою шприца 
Огляди літератури, оригінальні дослідження, погляд на проблему, випадок з практики, короткі повідомлення ін'єкційного інсулінового в дозі 40 мкл (1 мг/мл) через день протягом 2 тижнів [10]; III - щури з ліпополісахаридним пародонтитом на тлі хронічного атрофічного гастриту. У тварин цієї групи атрофічний гастрит викликали шляхом інтрагастрального введення протягом 6 тижнів 2 \% саліцилату натрію. Питну воду при цьому замінювали на 20 мМ деоксихолату натрію [11]. Розвиток атрофічного гастриту підтверджували гістологічними дослідженнями. Починаючи з 43 доби після введення саліцилату натрію тваринам протягом 2 тижнів вводили в тканини ясен лПС за вищеописаною методикою.

Щурів декапітували під тіопенталовим наркозом на наступний день після останнього введення лПС. Для морфологічного дослідження пародонта виділяли фрагмент верхньої щелепи. Шматочки фрагментів тканин пародонта фіксували в $10 \%$ розчині забуференого нейтрального формаліну протягом двох тижнів з триразовою зміною фіксуючого розчину. Розчин формаліну виготовляли безпосередньо перед використанням. Після фіксації у формаліні проводили декальцинацію тканин щелепи. Потім матеріал відмивали в проточній воді, зневоднювали у розчинах етилового спирту зростаючої концентрації й ущільнювали парафіном. Просочування препаратів парафіном здійснювали при температурі $56^{\circ}$ протягом 2 годин. Виготовлення серійних парафінових зрізів товщиною 4-6 мкм проводили на санному мікротомі MC-1. Фарбування препаратів здійснювали гематоксиліном і еозином [12]. Гістологічні препарати вивчали за допомогою світлового мікроскопа SEOSCAN та фотодокументували за допомогою відеокамери Vision CCD Camera. Такі класичні методи досліджень дають можливість вивчити структуру тканин, а також характер і глибину морфологічних змін, послідовність розвитку деструктивних та регенераторних процесів.

Результати й обговорення. Гістологічна організація структурних компонентів ясен інтактних щурів. В яснах розрізняють дві частини: вільну та прикріплену. Слизова оболонка вільної частини утворена епітеліальною пластинкою та сполучною тканиною, що має сосочковий і сітчастий шари. Епітеліальна пластинка вільної частини ясен представлена багатошаровим плоским зроговілим епітелієм. Смужка зроговілого шару в тварин інтактної групи нетовста, наявні ділянки його часткового відшарування. Базальний шар епітеліоцитів розташований на базальній мембрані, пухка сполучна тканина власної пластинки утворює сосочки, випинання в епітеліальну пластинку (рис. 1).

Епітеліоцити базального шару мають призматичну або циліндричну форму, між ними вияв-

ляються інтраепітеліальні лімфоцити. Клітини остистого шару розташовані у декілька рядів, мають специфічну форму з короткими відростками та розвинені міжклітинні десмосомні контакти.

у епітеліальній пластинці вільної частини ясен щурів клітини поступово стають витягнутими, плоскими, спостерігаються розширені міжклітинні проміжки. Виявляється каріопікноз із подальшим лізисом цитоплазми, тому роговий шар епітелію складають без'ядерні рогові лусочки, які періодично десквамуються.

Слизова оболонка ясен щурів має власну пластинку, яка утворена сполучною тканиною і в якій можна виділити сосочковий і сітчастий шари у вільній частині і сітчастий - в проекції нижньої третини ясенної борозни, який без чітких меж переходить у сполучну тканину періодонта.

У пухкій сполучній тканині сосочкового шару спостерігаються гемокапіляри, що мають неширокі просвіти, в яких наявні формені елементи крові, переважно еритроцити. У сосочковому шарі вільної частини ясен виявляються пучки колагенових волокон, між ними розташовані фібробласти, поодинокі периваскулярно розміщені лімфоцити і макрофаги.

Сітчастий шар власної пластинки слизової оболонки вільної частини ясен представлений щільною неоформленою сполучною тканиною, в якій пучки колагенових волокон мають різноспрямований хід і більшу товщину, порівняно із сосочковим шаром.

Епітеліальна пластинка слизової оболонки вільної частини ясен без чіткої межі переходить в епітелій борозни. Вона також складається з багатошарового плоского зроговілого епітелію, але

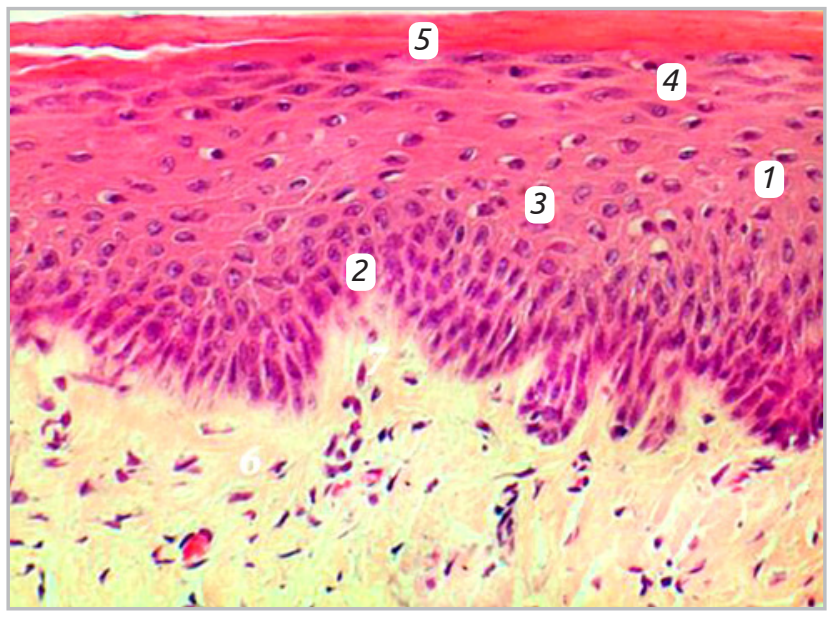

Рис. 1. Мікроскопічна організація слизової оболонки вільної частини ясен щура інтактної групи. Забарвлення гематоксиліном і еозином. × 200. 1 - епітеліальна пластинка; 2 - базальний шар; 3 - остистий шар; 4 зернистий шар; 5 - роговий шар; 6 - власна пластинка; 7 - сосочок. 
Огляди літератури, оригінальні дослідження, погляд на проблему, випадок з практики, короткі повідомлення товщина епітеліальної пластинки менша за рахунок рядів клітин остистого та рогового шарів. Пластинка представлена базальними клітинами, які за допомогою напівдесмосом з'єднані з базальною мембраною, остистими, зернистими та поверхневими роговими лусочками, що свідчить про процес кератинізації (ортокератоз) епітелію ясенної борозни у щурів (рис. 2).

В яснах добре розвинена судинна система, в сітчастому шарі власної пластинки ясен артерії

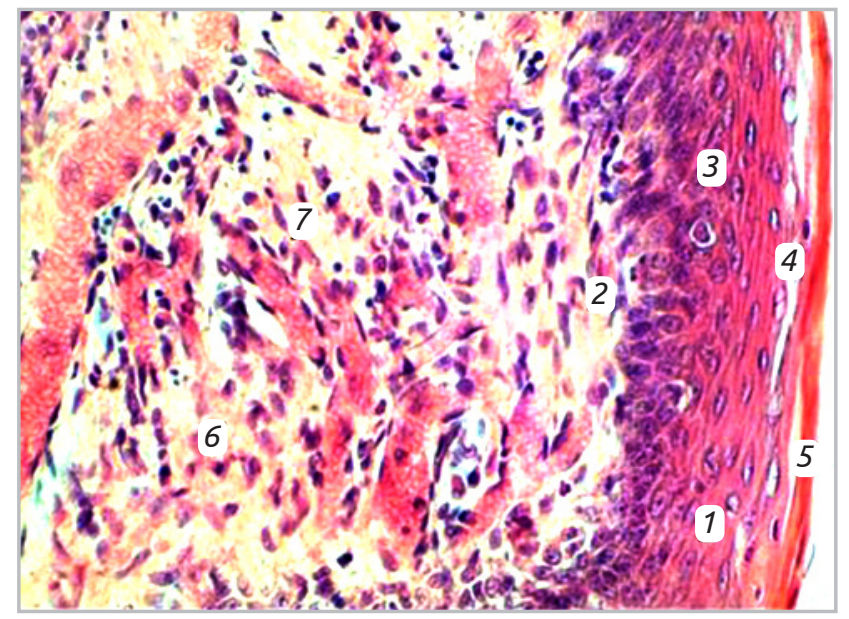

Рис. 2. Мікроскопічна організація слизової оболонки частини ясен в ділянці борозни щура інтактної групи. Забарвлення гематоксиліном і еозином. × 200. 1 епітеліальна пластинка; 2 - базальний шар; 3 - остистий шар; 4 - зернистий шар; 5 - роговий шар; 6 - власна пластинка; 7 - судини.

Гістологічні зміни структурних компонентів ясен щурів при ліпополісахаридному пародонтиті. Мікроскопічні дослідження ясен щурів при пародонтиті встановили виражені зміни в усіх їі структурних компонентах. Спостерігалось суттєве потовщення рогового шару епітеліальної пластинки, особливо у вільній ділянці ясен. Наявні ділянки порушення контактів між роговими лусочками. Це свідчить про явища гіперкератозу в епітелії вільної частини ясен щурів у відповідь на дію пошкоджувального чинника.

Також спостерігається зменшення товщини остистого шару цієї ділянки ясен. У багатьох епітеліоцитах каріоплазма ядер світлооптично прозора, тому вони виглядають вакуолеподібними. У епітеліоцитах зернистого шару в цитоплазмі багато базофільних гранул кератогіаліну (рис. 4).

Також мікроскопічно спостерігається зменшення товщини епітеліальної пластинки слизової оболонки ясен у ділянках борозни та прикріплення. На відміну від щурів інтактної групи, у епітеліальній пластинці борозни ядра клітин остистого шару мають невеликі розміри, базофільну каріо- формують глибоке сплетення і дають вертикальні гілочки, що пронизують сітчастий шар та утворюють капілярні сплетення в сосочках. Судини мікроциркуляторного русла в сітчастому шарі представлені артеріолами та венулами (рис. 3). Судини мікроциркуляторного русла, які виявляються під епітелієм борозни - артеріоли, капіляри і венули - є основним місцем міграції лейкоцитів (нейтрофільних гранулоцитів і макрофагів) до просвіту борозни через епітелій прикріплення.

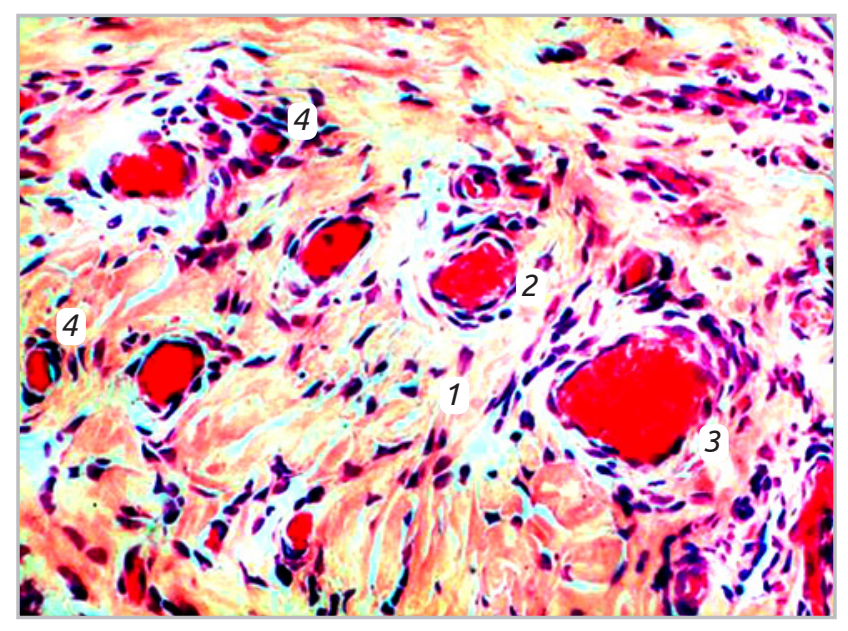

Рис. 3. Мікроскопічна організація судин власної пластинки слизової оболонки вільної частини ясен щура інтактної групи. Забарвлення гематоксиліном і еозином. × 200. 1 - сполучна тканина власної пластинки; 2 - артеріола; 3 - венула; 4 - гемокапіляри.

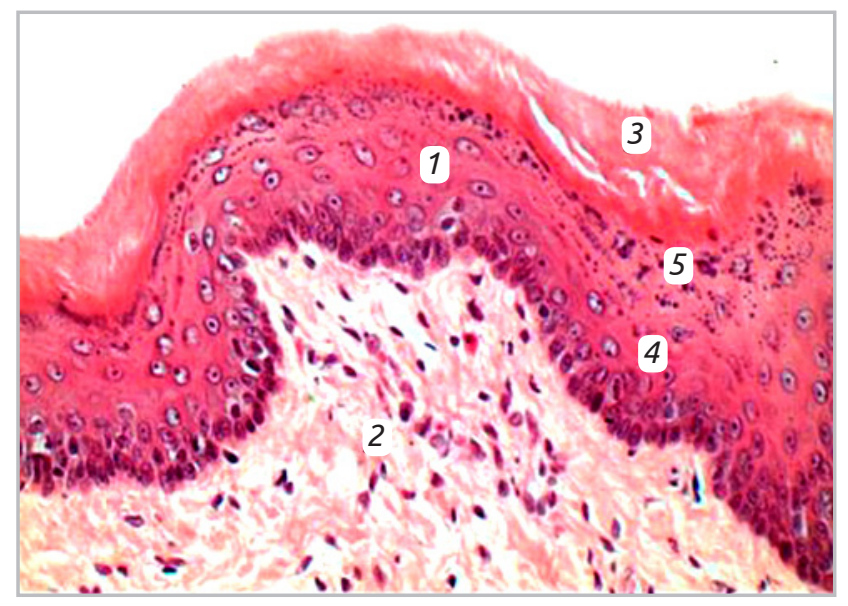

Рис. 4. Мікроскопічні зміни слизової оболонки вільної ділянки ясен щура при експериментальному пародонтиті. Забарвлення гематоксиліном і еозином. $\times 200$. 1 - епітеліальна пластинка; 2 - власна пластинка; 3 - роговий шар; 4 - остистий шар; 5 - зернистий шар.

плазму, що свідчить про їх пікнотичні зміни. У розширених міжклітинних просторах відмічаються лімфоцити, поодинокі макрофаги і нейтрофільні 
Огляди літератури, оригінальні дослідження, погляд на проблему, випадок з практики, короткі повідомлення гранулоцити. Мітотичний поділ епітеліоцитів базального шару відбувається рідко (рис. 5).

У власній пластинці слизової оболонки ясен спостерігаються порушення структури сполучної тканини та судинні розлади. Наявні набряк аморфного компонента міжклітинної речовини, деструктивні зміни волокон, які проявляються дезорганізацією та стоншанням колагенових волокон. Сітчастий шар сполучної тканини ясен складають ущільнені пучки колагенових волокон, які мають інтенсивно оксифільне забарвлення, а між пучками наявні світлі, неправильної форми

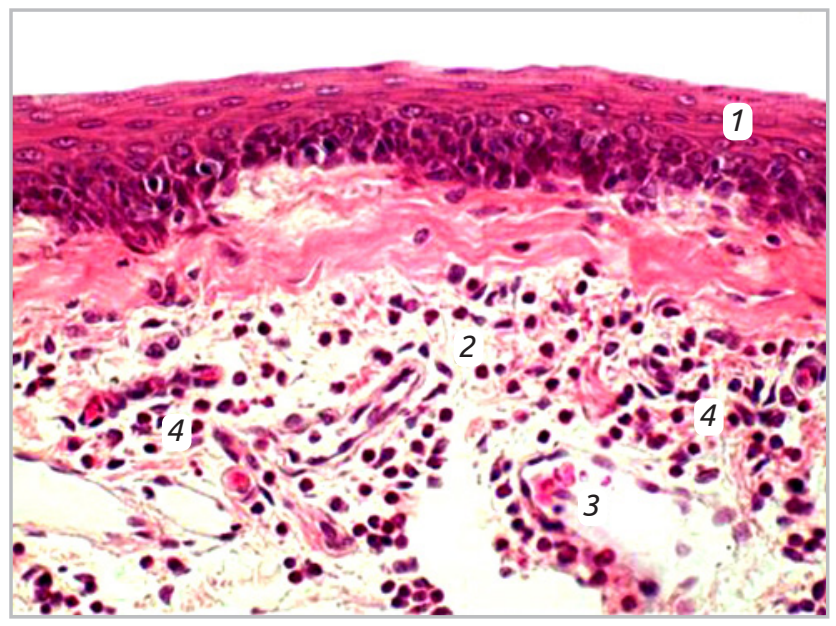

Рис. 5. Мікроскопічні зміни слизової оболонки ділянки прикріплення ясен щура при експериментальному пародонтиті. Забарвлення гематоксиліном і еозином. × 200. 1 - епітеліальна пластинка; 2 - власна пластинка; 3 - судини; 4 - лейкоцитарна інфільтрація власної пластинки.

У периваскулярних просторах виявляються дрібновогнищеві інфільтрати. Біля стінки гемокапілярів спостерігаються тканинні базофіли - опасисті клітини, які мають ознаки дегрануляції. В епітелії вільної частини ясен і ясенної борозни відмічається підвищення кількості інтраепітеліальних лімфоцитів.

Гістологічні зміни структурних компонентів ясен щурів при пародонтиті на фоні гастриту. Мікроскопічні дослідження ясен щурів при пародонтиті на фоні гастриту показали, що зміни їх структурних компонентів подібні до таких у групі тварин з пародонтитом, проте вони були більш виражені. У епітеліальній пластинці слизової оболонки, крім потовщення рогового шару, спостерігались ділянки його відшарування та утворення інвагінацій, заповнених роговими лусочками. Це відображає розвиток гіперкератозу в епітелії вільної частини ясен.

Товщина остистого і рогового шарів зменшена навіть порівняно з групою тварин із експери-

ділянки аморфного компонента, що свідчить про набряк. Відмічається пошкодження фібробластів, наявність фіброцитів, підвищується лейкоцитарна інфільтрація, особливо ділянок сполучної тканини борозни та прикріплення (рис. 5).

Виявляються значні зміни в компонентах мікроциркуляторного русла власної пластинки ясен. Для артеріол характерні суттєве зменшення площ просвіту, потовщення стінки, периваскулярний набряк. Збільшуються просвіти венул і капілярів, вони кровонаповнені, стінка їх стоншена (рис. 6).

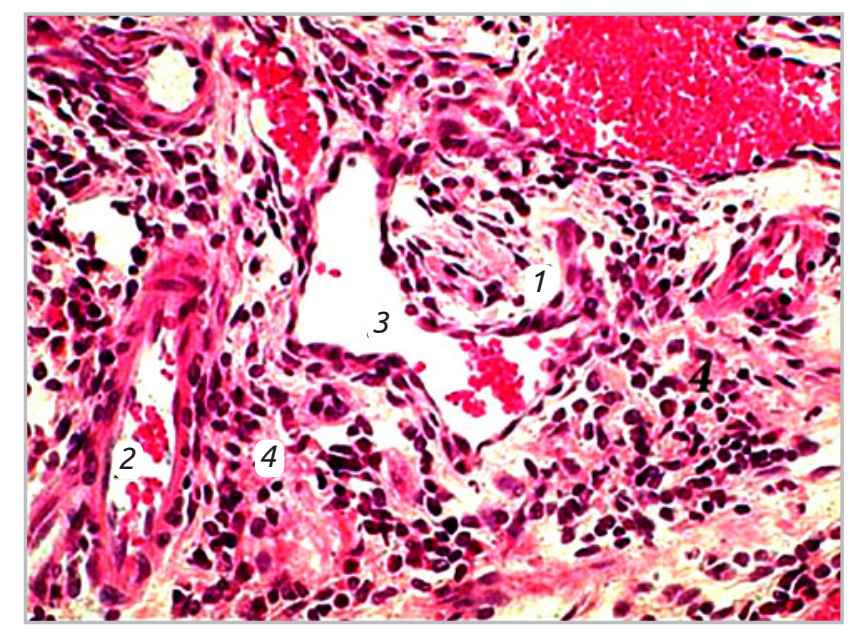

Рис. 6. Мікроскопічні зміни власної пластинки слизової оболонки ділянки ясенної борозни щура при експериментальному пародонтиті. Забарвлення гематоксиліном і еозином. × 200. 1 - власна пластинка; 2 - артеріола; 3 - венула; 4 - лейкоцитарна інфільтрація власної пластинки.

ментальним пародонтитом. У епітеліоцитах базального шару каріоплазма ядер базофільна, вони невеликі. Між такими клітинами наявні мігруючі лімфоцити. У остистому шарі чисельність клітин зменшена навіть у рядах. Чіткі плазмолеми між клітинами відсутні (рис. 7).

Гістологічно в епітеліальній пластинці слизової виявляються ділянки, у яких мігруючі лімфоцити утворюють скупчення, що свідчить про значну деструкцію нижніх шарів клітин і розвиток запального процесу (рис. 8).

Розвиток більш значного пошкодження епітеліальної пластинки слизової оболонки виявляється також у ділянках борозни та прикріплення. На поверхні епітеліальної пластинки борозни спостерігається шар злущених клітин, у якому наявні пошкоджені й загиблі лейкоцити. Запальна реакція і вихід лімфоцитів на поверхню виявляється в більш тонких ділянках епітеліальної пластинки. У базальному шарі відмічаються клітини 3 невеликими базофільними ядрами, невеликою 
Огляди літератури, оригінальні дослідження, погляд на проблему, випадок з практики, короткі повідомлення

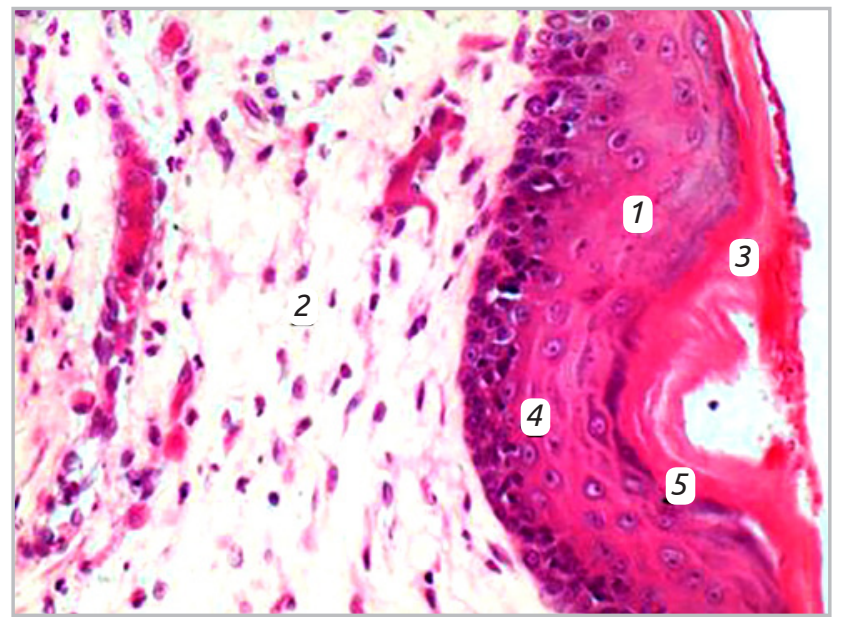

Рис. 7. Мікроскопічні зміни слизової оболонки вільної ділянки ясен щура при експериментальному пародонтиті та гастриті. Забарвлення гематоксиліном і еозином. x 200. 1 - епітеліальна пластинка, 2 - власна пластинка, 3 - роговий шар, 4 - остистий шар, 5 - зернистий шар.

площею цитоплазми. Мітотичний поділ епітеліоцитів виявляється рідко. У остистому шарі мало рядів клітин, як і у зернистому (рис. 9).

У слизовій оболонці ясен тварин відмічаються значні зміни структурних компонентів мікроциркуляторного русла. Артеріоли мають потовщену стінку, вузькі просвіти. Просвіти венул і капілярів навпаки, значно збільшені, кровонаповнені, а стінки їх стоншені. В окремих ділянках наявні пошкодження стінки судин і крововиливи (рис. 10). Такий стан судин свідчить про порушення кровотоку і застійні явища.

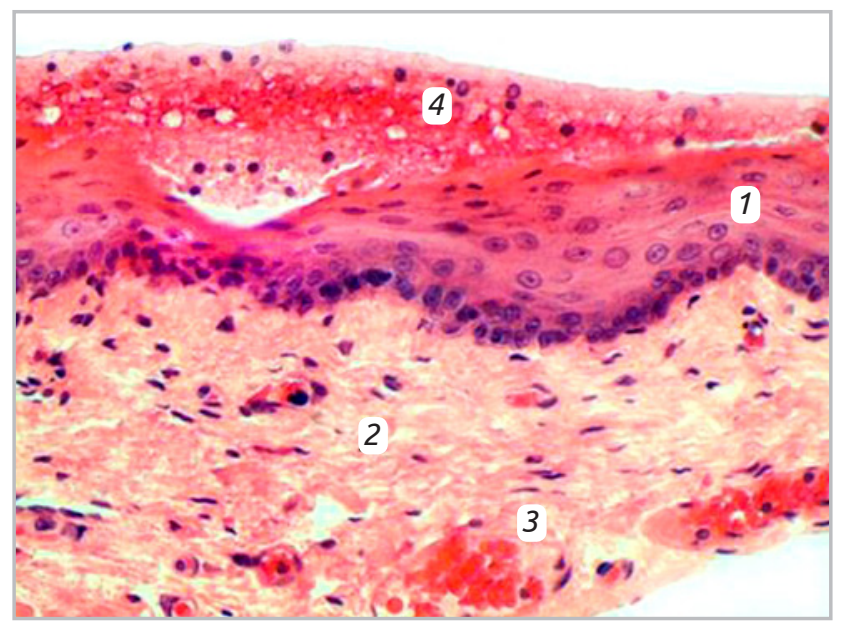

Рис. 9. Мікроскопічні зміни слизової оболонки ділянки прикріплення ясен щура при експериментальному пародонтиті та гастриті. Забарвлення гематоксиліном і еозином. ×300. 1 - епітеліальна пластинка; 2 власна пластинка; 3 - судина; 4 - інфільтрат на поверхні епітелію.

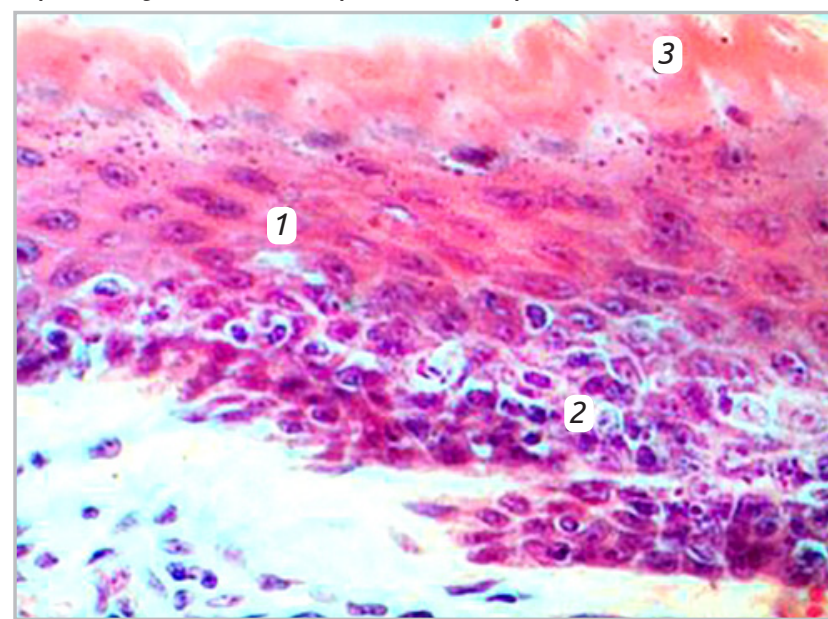

Рис. 8. Мікроскопічні зміни епітеліальної пластинки слизової оболонки вільної ділянки ясен щура при експериментальному пародонтиті та гастриті. Забарвлення гематоксиліном і еозином. × 400. 1 - епітеліальна пластинка, 2 - виразна інфільтрація базального і остистого шарів, 3 - роговий шар.

У ділянці борозни власна пластинка значно інфільтрована, скупчення лейкоцитів наявні у периваскулярному просторі, а також у сполучній тканині власної пластинки слизової оболонки ясен (рис. 11).

У власній пластинці слизової оболонки ясен наявні набряк аморфного компонента міжклітинної речовини, деструктивні зміни волокон. У сітчастому шарі сполучної тканини вільної частини ясен також виражений набряк. Ще більший набряк і лейкоцитарна інфільтрація спостерігаються у ділянках борозни і прикріплення.

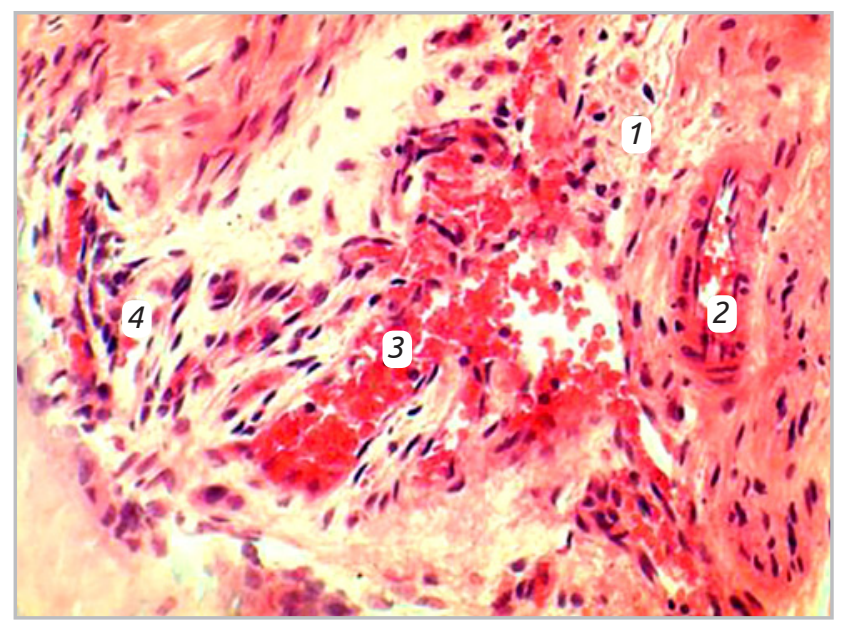

Рис. 10. Мікроскопічні зміни власної пластинки слизової оболонки ділянки ясенної борозни щура при експериментальному пародонтиті та гастриті. Забарвлення гематоксиліном і еозином. × 200. 1 - власна пластинка; 2 - артеріола; 3 - венула; 4 - лейкоцитарна інфільтрація власної пластинки. 
Огляди літератури, оригінальні дослідження, погляд на проблему, випадок з практики, короткі повідомлення

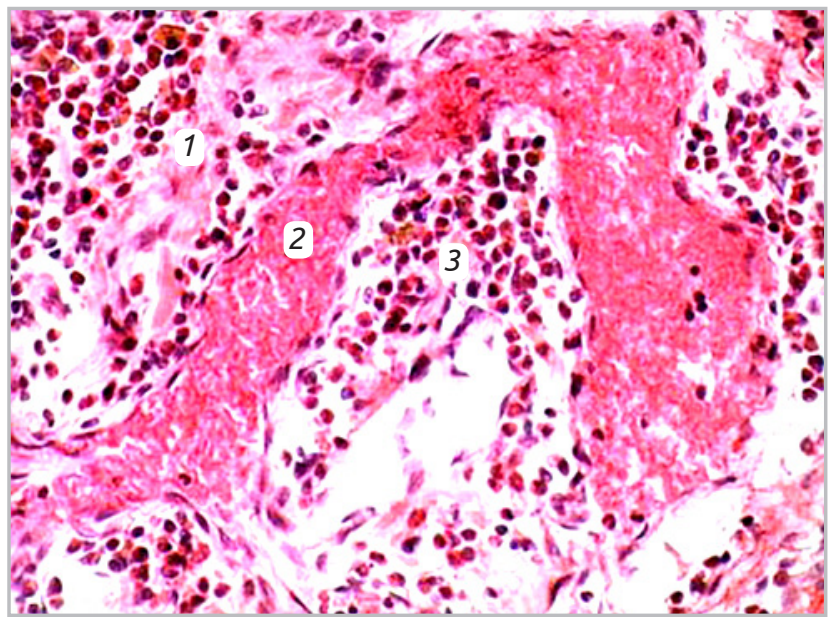

Рис. 11. Мікроскопічні зміни власної пластинки слизової оболонки ділянки ясенної борозни щура при експериментальному пародонтиті та гастриті. Забарвлення гематоксиліном і еозином. x 200. 1 - власна пластинка; 2 - венула; 3 - лейкоцитарна інфільтрація власної пластинки.

Такі морфологічні зміни тканин ясен при пародонтиті та пародонтиті на фоні гастриту можуть бути зумовленими активізацією вільнорадикальних реакцій у тканинах під впливом ліпополісахариду та порушенням функціонування системи антиоксидного захисту, тобто так званим оксидативним стресом [13]. Відомо, що вільні кисневі радикали деструктивно діють на біомембрани та інші клітинні структури, сприяючи розвитку запального процесу в тканинах [14]. Одне з провідних місць у патогенезі запалення займають порушення мікроциркуляції. Розлади в системі мікроциркуляції мають місце й у хворих на генералізований пародонтит. У мікроциркуляторному руслі пародонта знижуються показники тонусу судин, індексів периферійного опору й еластичності судин, розвивається сладж-синдром. Безпосередньою причиною розладів мікроциркуляції $є$ ендотеліальна дисфункція, що великою мірою залежить від біодоступності оксиду азоту (NO), який виробляється ендотеліальною формою NO-синтази. При запальному ураженні зазвичай має місце гіперекспресія індуцибельної форми NO-синтази (iNOS), що призводить до продукції надмірної кількості NO, який також може відігравати роль важливого ефектора у механізмах розвитку запалення, генерованого бактеріальним ендотоксином [13]. Потужними активаторами iNOS при ліпополісахаридному пародонтиті $\epsilon$ прозапальні цитокіни, які стимулюють розвиток запальних реакцій і дезагрегацію тканин ясен [15].

Ми спостерігали деяке погіршання патоморфологічної картини структур пародонта у тварин з пародонтитом на фоні атрофічного гастриту, по- рівняно з тваринами із пародонтитом без гастриту. Може бути декілька механізмів такого негативного впливу супутньої гастроентерологічної патології на тканини пародонта. При хронічному гастриті можуть посилено вироблятися травні гормони (гастрин, холецистокінін тощо), які, прямо чи опосередковано діючи на С-клітини щитоподібної залози, збільшують продукцію кальцитоніну, що призводить до виснаження С-клітин щитоподібної залози й збільшення вироблення паратиреоїдного гормону. Це, у свою чергу, викликає резорбтивні процеси в сполучній тканині пародонта $[9,16]$. Крім того, при хронічному гастриті порушується ряд регуляторних механізмів, що створює умови для розвитку пародонтиту. 3окрема, змінюється імунна реактивність організму (має місце недостатня кількість активних форм нейтрофілів, знижуються вміст Т-лімфоцитів і їх функціональна активність $[17,18])$, виникає ендокринний дисбаланс, відбуваються порушення мікроциркуляції, нейрогуморальної регуляції, змінюється метаболізм сполучної тканини, мінеральний обмін, виникає дефіцит вітамінів [19-21]. Усе це призводить до ослаблення резистентності організму і на цьому фоні під впливом ендотоксинів грамнегативних бактерій виникає виражена запальна реакція тканин ротової порожнини.

Висновки. 1. Проведені гістологічні дослідження ясен тварин при експериментальному пародонтиті дозволили виявити реорганізацію всіх iї структурних компонентів, порівняно з тваринами контрольної групи. Вона проявляється змінами епітелію слизової оболонки ясен, як вільної, так і ділянок борозни та прикріплення, збільшенням зроговілого шару, зменшенням остистого шару, розширенням міжклітинних просторів, зростанням лімфоцитарної інфільтрації, набряком сполучної тканини слизової оболонки. Реакція судинного русла на змодельований пародонтит проявляється розширенням, кровонаповненням вен і гемокапілярів та звуженням i потовщенням стінки артерій. Сполучна тканина слизової оболонки характеризується набряком аморфної речовини і пошкодженням волокнистих структур.

2. При експериментальному пародонтиті на фоні гастриту виявляються значні пошкодження всіх структурних компонентів пародонта. Реорганізація епітелію слизової оболонки ясен, як вільної, так і ділянок борозни та прикріплення, характеризується вираженим потовщенням зроговілого шару, зменшенням остистого шару, деструкцією епітеліоцитів базального шару. Ще більшою мірою зростає лімфоцитарна інфільтрація внаслідок руйнування міжклітинних контактів та розширення міжклітинних просторів. Розширення, кро- 
Огляди літератури, оригінальні дослідження, погляд на проблему, випадок з практики, короткі повідомлення вонаповнення вен і гемокапілярів та звуження і потовщення стінок артерій спостерігається в більшій мірі, ніж у щурів з пародонтитом без супутнього гастриту. Застійні явища та погіршання трофіки структур ясен супроводжуються набряком сполучної тканини слизової оболонки та пошкодженням її волокнистих структур.

Перспективи подальших досліджень. Отримані нами результати можуть слугувати основою для подальшого поглибленого вивчення патогенезу запального ураження пародонта ендотоксином грамнегативної мікрофлори ліпополісахаридом за умови супутнього хронічного атрофічного гастриту. Необхідно дослідити фундаментальні біохімічні зміни в тканинах пародонта за даної патології і встановити їх взаємозв'язок із патоморфологічною картиною, описаною в даній роботі.

\section{ЛІТЕРАТУРА}

1. Periodontitis among adult populations in the Arab World / L. S. Al-Harthi, M. P. Cullinan, J. W. Leichter [et al.] // Int. Dent. J. - 2013. - Vol. 63, No. 1. - P. 7-11.

2. State of the science: chronic periodontitis and systemic health / J. Otomo-Corgel, J. J. Pucher, M. P. Rethman [et al.] // J. Evid. Based Dent. Pract. - 2012. - Vol. 12, No. 3. P. 20-28.

3. Current status of periodontal risk assessment / W. Kye, R. Davidson, J. Martin, S. Engebretson // J. Evid. Based. Dent. Pract. - 2012. - Vol. 12, No. 3. - P. 2-11.

4. Батіг В. М. Поширеність і інтенсивність захворювань пародонту в працівників підприємств хімії органічного синтезу / В. М. Батіг // Буковин. мед. вісник. 2010. - T. 14, № 1. - C. 9-13.

5. Stage of hepatocellular carcinoma is associated with periodontitis / N. Tamaki, A. Takaki, T. Tomofuji [et al.] // J. Clin. Periodontol. -2011. - Vol. 38, No. 11. - P. 1015-1020.

6. Amano A. Cardiovascular diseases and periodontal diseases / A. Amano, H. Inaba // Clin. Calcium. - 2012. Vol. 22, No. 1. - P. 43-48.

7. Levine R. S. Obesity, diabetes and periodontitis - a triangular relationship? / R. S. Levine // Br. Dent. J. - 2013. Vol. 215, No. 1. - P. 35-39.

8. Clinical review: Association between metabolic syndrome and periodontitis: a systematic review and meta-analysis / L. Nibali, N. Tatarakis, I. Needleman [et al.] // J. Clin. Endocrinol. Metab. - 2013. - Vol. 98, No. 3. P. 913-920.

9. Еремин О. В. Коморбидность болезней пародонта и желудочно-кишечного тракта / О. В. Еремин, А. В. Лепилин, И. В. Козлова // Саратовский научно-медицинский журнал. - 2009. - Т. 5, № 3. - С. 393-398.

10. Моисеева Е. Г. Метаболический гомеостаз и имунная реактивность организма в динамике воспаления в тканях пародонта (экспериментальное исследование) : автореф. дис. на соискание ученой степени доктора мед. наук : спец. 14.00.16 «Патологическая физиология» / Е. Г. Моисеева. - М., 2008. - 45 с.

11. Morphological and pathologic changes of experimental chronic atrophic gastritis (CAG) and the regulating mechanism of protein expression in rats / L. Wang, S. Chen, Z. Chen [et al.] // J. Zhejiang Univ. SCIENCE B. - 2006. Vol. 7, No. 8. - P. 634-640.

12. Сорочинников А. Г. Гистологическая и микроскопическая техника / А. Г. Сорочинников, А. Е. Доросевич. - Смоленск : САУ, 2000.- 480 с.

13. Беденюк О. С. Роль оксидативного і нітрооксидативного стресу в патогенезі генералізованого пародонтиту на фоні хронічного гастриту / О. С. Беденюк, М. М. Корда // Медична та клінічна хімія. - 2016. - Т. 18, № 4. - С. 11-15.

14. Беденюк О. С. Біохімічна характеристика стану сполучної тканини при ліпополісахаридному пародонтиті на тлі хронічного гастриту / О. С. Беденюк, М. М. Корда // Science of Europe. - 2018. - Vol. 2, No. 27. - C. 18-22.

15. Беденюк О. С. Імунна реактивність організму при генералізованому пародонтиті на фоні хронічного атрофічного гастриту / О. С. Беденюк, М. М. Корда // Вісник проблем біології і медицини. - 2018. - Т. 2, № 1. C. $85-88$.

16. Логинова Н. К. Патофизиология пародонта : учебно-метод. пособие / Н. К. Логинова, А. И. Воложин. - М., 1993. -80 с.

17. Орехова Л. Ю. Клинико-иммунологические и микробиологические параллели при хроническом генерализованном пародонтите и язвенной болезни желудка / Л. Ю. Орехова, Д. М. Нейзберг, И. Ю. Стюф // Стоматология. - 2006. - № 6. - С. 22-26.

18. Орехова Л. Ю. Показатели клеточной сенсибилизации при воспалительных заболеваниях пародонта / Л. Ю. Орехова, М. Я. Левин // Новое в стоматологии. - 1998. - № 7. - С. 71-74.

19. Цепов Л. М. Факторы агрессии и факторы защиты в патологии пародонта воспалительного характера/ Л. М. Цепов, А. И. Николаев, Е. А. Михеева// Пародонтология. - 2004. - №1 (30). - С. 3-7.

20. Горбачева И. А. Единство системных патогенетических механизмов при заболеваниях внутренних органов, ассоциированных с генерализованным пародонтитом / И. А. Горбачева, А. И. Кирсанов, Л. Ю. Орехова // Стоматология. - 2004. - № 3. - С. 6-11.

21. Лепилин А. В. Влияние комплексной эрадикации helicobacter pylori на стоматологический статус больных язвенной болезнью двенадцатиперстной кишки / А. В. Лепилин, М. А. Осадчук, Л. Ю. Островская // Рос. стоматологический журнал. - 2006. - № 2. - С. 27-29. 
Огляди літератури, оригінальні дослідження, погляд на проблему, випадок з практики, короткі повідомлення REFERENCES

1. Al-Harthi, L.S., Cullinan, M.P., \& Leichter, J.W. (2013). Periodontitis among adult populations in the Arab World. Int. Dent. J., 63 (1), 7-11.

2. Otomo-Corgel, J., Pucher, J.J., \& Rethman, M.P. (2012). State of the science: chronic periodontitis and systemic health. J. Evid. Based. Dent. Pract., 12 (3), 20-28.

3. Kye, W., Davidson, R., Martin, J., \& Engebretson, S. (2012). Current status of periodontal risk assessment. J. Evid. Based. Dent. Pract., 12 (3), 2-11.

4. Batih, V.M. (2010). Poshyrenist i intensyvnist zahvoriuvan parodontu $v$ pratsivnykiv pidpryiemstv khimii orhanichnoho syntezu [Prevalence and intensity of periodontal diseases in employees of organic chemistry enterprises]. Bukovynskyi medychnyi visnyk - Bukovyna Medical Bulletin, 14 (1), 9-13 [in Ukrainian].

5. Tamaki, N., Takaki, A., \& Tomofuji, T. (2011). Stage of hepatocellular carcinoma is associated with periodontitis. J. Clin. Periodontol., 38 (11), 1015-1020.

6. Amano, A., \& Inaba, H. (2012). Cardiovascular diseases and periodontal diseases. Clin. Calcium., 22 (1), 43-48.

7. Levine, R.S. (2013). Obesity, diabetes and periodontitis - a triangular relationship? Br. Dent. J., 215 (1), 35-39.

8. Nibali, L., Tatarakis, N., \& Needleman, I. (2013). Clinical review: Association between metabolic syndrome and periodontitis: a systematic review and meta-analysis. J. Clin. Endocrinol. Metab., 98 (3), 913-920.

9. Yeromin, O.V., Lepilin, A.V., \& Kozlova, I.V. (2009). Komorbidnost bolezney parodonta i zheludochno-kishechnogo trakta [Comorbidity of periodontal diseases and gastrointestinal tract]. Saratovskiy nauchno-meditsinskiy zhurnal - Saratov Scientific-medical Journal, 5 (3), 393-398 [in Russian].

10. Moyseyeva, E.G. (2008). Metabolicheskiy gomeostaz i imunnaya reaktivnost organizma v dinamike vospalyeniya $v$ tkanyah parodonta (eksperimentalnoye isslyedovaniye): avtoreferat [Metabolic homeostasis and immune reactivity of the body in the dynamics of inflammation in periodontal tissues (experimental study)]. Doctor's Extended abstract [in Russian]

11. Wang, L., Chen, S., \& Chen, Z. (2006). Morphological and pathologic changes of experimental chronic atrophic gastritis (CAG) and the regulating mechanism of protein expression in rats. J. Zhejiang Univ. SCIENCE B, 7 (8), 634-640.

12. Sorochnnikov, A.G., \& Dorosevich, A.E. (2000). Gistologicheskaya i mikroskopicheskaya tekhnika [Histological and microscopic technique]. Smolyensk-Smolensk: SAU [in Russian].

13. Bedeniuk, O.S., \& Korda, M.M. (2016). Rol oksydatyvnoho i nitrooksydatyvnoho stresu v patohenezi heneralizovanoho parodontytu na foni khronichnoho hastrytu [The role of oxidative and nitrooxidative stress in the patho- genesis of generalized periodontitis on the background of chronic gastritis]. Medychna ta klinichna khimiia - Medical and Clinical Chemistry, 18 (4), 11-15 [in Ukrainian].

14. Bedeniuk, O.S., \& Korda, M.M. (2018). Biokhimichna kharakterystyka stanu spoluchnoi tkanyny pry lipopolisaharydnomu parodontyti na tli khronichnoho hastrytu [Biochemical characterization of connective tissue condition in lipopolysaccharide periodontitis on the background of chronic gastritis]. Science of Europe, 2 (27), 18-22 [in Ukrainian].

15. Bedeniuk, O.S., \& Korda, M.M. (2018). Imunna reaktyvnist orhanizmu pry heneralizovanomu parodontyti na foni khronichnoho atrofichnoho hastrytu [Immune reactivity of the body in generalized periodontitis on the background of chronic atrophic gastritis]. Visnyk problem biolohii i medytsyny - Bulletin of Problems of Biology and Medicine, 2 (1), 85-88 [in Ukrainian].

16. Loginova, N.K. (1993). Patofiziologiya parodonta: uchebno-metod. posobiye [Pathophysiology of the periodontium: a textbook]. [in Russian].

17. Orekhova, L.Yu., Neyzberg, D.M., \& Styuf, I.Yu. (2006). Kliniko-immunologicheskiye i mikrobiologicheskiye parallyeli pri khronicheskom generalizovanom parodontitye i yazvennoy bolezni zheludka [Clinical-immunological and microbiological parallels in chronic generalized periodontitis and gastric ulcer]. Stomatologiya-Dentistry, (6), 2226 [in Russian].

18. Orekhova, L.Yu., \& Levin, M.Ya. (1998). Pokazateli kletochnoy sensibilizatsii pri vospalitelnykh zabolevaniyakh parodonta [Indicators of cellular stabilization in inflammatory periodontal diseases]. Novoe $v$ stomatologii - New in Dentistry, (7), 71-74 [in Russian].

19. Tsepov, L.M., Nikolayev, A.I.,b \& Miheyeva, Ye.A. (2004). Faktory agresii i faktory zashchity v patologii parodonta vospalityelnogo haraktera [Aggression and protection factors in inflammatory periodontal pathology]. Paradontologiya-Periodontics, 30 (1), 3-7 [in Russian].

20. Gorbachova, I.A., Kirsanov, A.I., \& Orekhova, L.Yu. (2004). Yedinstvo sistemnykh patologicheskikh mekhanizmov pri zabolyevaniyakh vnutryennikh organov, assotseirovannykh s generalizirovannym parodontitom [Unity of systemic pathological mechanisms in diseases of internal organs associated with generalized periodontitis]. Stomatologiya - Dentistry, (3), 6-11 [in Russian].

21. Lepilin, A.V., Osadchuk, M.A., \& Ostrovskaya, L.Yu. (2006). Vliyaniye komplyeksnoy eradikatsii helicobacter pylori na stomatologicheskiy status bolnykh yazvennoy boleznyu dvenadtsatiperstnoy kishki [The effect of complex eradication helicobacter pylori on the dental status of patients with peptic ulcer of the duodenum]. Ros. stomatologicheskiy zhurnal - Russian Dental Journal, (2), 27-29 [in Russian]. 

ПАРОДОНТИТА НА ФОНЕ ХРОНИЧЕСКОГО АТРОФИЧЕСКОГО ГАСТРИТА

\author{
๑А. С. Беденюк, М. М. Корда
}

Тернопольский национальный медицинский университет имени И. Я. Горбачевского Мз Украины

PЕЗЮМЕ. Воспалительные заболевания тканей пародонта являются одной из важнейших проблем в стоматологии. Существует устойчивая связь между патологией пародонта и воспалительными заболеваниями желудка.

Цель - исследовать патоморфологические изменения в тканях пародонта крыс с генерализованным липополисахаридным пародонтитом, ассоциированным с хроническим атрофическим гастритом.

Материал и методы. У крыс моделировали генерализованный липополисахаридный пародонтит путем введения в ткани десен липополисахарида в дозе 40 мкл (1 мг/мл) в течение 2 недель. Атрофический гастрит вызвали путем интрагастрального введения в течение 6 недель 2 \% салицилата натрия и 20 мМ деоксихолата натрия. Гистологические препараты фрагментов верхней челюсти окрашивали гематоксилином и эозином.

Результаты. При генерализованном липополисахаридном пародонтите происходит реорганизация всех структурных компонентов тканей десен. Она проявляется изменениями эпителия слизистой оболочки десен, увеличением ороговевшего и уменьшением остистого слоев, расширением межклеточных пространств, ростом лимфоцитарной инфильтрации, отеком соединительной ткани, расширением вен и гемокапилляров, утолщением стенки артерий, отеком аморфного вещества соединительной ткани и повреждением ее волокнистых структур. При пародонтите на фоне гастрита все структурные изменения проявляются в большей степени, чем у животных с пародонтитом без соматической патологии.

Вывод. Сопутствующий хронический атрофический гастрит существенно ухудшает патоморфологическую картину пародонтита, индуцированного у животных эндотоксином грамотрицательной микрофлоры липополисахаридом.

КЛЮчЕВЫЕ СЛОВА: пародонтит; атрофический гастрит; морфологические изменения.

\title{
PATHOMORPHOLOGICAL FEATURES OF THE LIPOPOLYSACCHARIDE PERIODONTITIS DEVELOPMENT ASSOCIATED WITH CHRONIC ATROPHIC GASTRITIS
}

๑O. S. Bedenyuk, M. M. Korda

\section{Horbachevsky Ternopil National Medical University}

SUMMARY. Inflammatory diseases of periodontal tissues are one of the most important problems in dentistry. There is a strong association between periodontal pathology and inflammatory diseases of the stomach.

The aim of the work was to study the pathomorphological changes in the periodontal tissues of rats with generalized lipopolysaccharide periodontitis associated with chronic atrophic gastritis.

Material and Methods. In rats, generalized lipopolysaccharide periodontitis was modeled by introducing 40 microliters $(1 \mathrm{mg} / \mathrm{ml})$ of lipopolysaccharide into the gum tissue for 2 weeks. Atrophic gastritis was caused by intragastric administration for 6 weeks with $2 \%$ sodium salicylate and $20 \mathrm{mM}$ sodium deoxycholate. Histological preparations of the upper jaw fragments were stained with hematoxylin and eosin.

Results. In generalized lipopolysaccharide periodontitis the reorganization of all structural components of the gum tissues occurs. It is manifested by changes in the epithelium of the mucous membrane of the gums, an increase in the stratum corneum, a decrease in the spinous layer, an expansion of the intercellular spaces, an increase in lymphocytic infiltration, swelling of the connective tissue, expansion of the veins and hemocapillaries, thickening of the walls of arteries, swelling of the amorphous substance of the connective tissue and damage to its fibrous structures. In periodontitis on the background of gastritis, all structural changes are manifested to a greater extent than in animals with periodontitis without somatic pathology.

Conclusion. Concomitant chronic atrophic gastritis significantly worsens the pathomorphological picture of periodontitis induced in animals by endotoxin of gram-negative microflora lipopolysaccharide.

KEY WORDS: periodontitis; atrophic gastritis; morphological changes. 